\title{
Observations regarding the lexical content at the beginnings of structural semantics
}

\author{
Dinu Moscal ${ }^{*}$ \\ “A. Philippide” Institute of Romanian Philology, Str. Th. Codrescu 2, 700481 Iași, Romania
}

\section{Article info}

History:

Received April 11, 2019

Accepted April 16, 2019

Published May 7, 2019

Key words:

semantics

structuralism

lexicology

lexical field

diachrony

\begin{abstract}
This study focuses on the difficulties noted by a series of German lexicologists at the beginnings of structural semantics as part of their attempt to identify a possible method of organizing the lexis of a language. Their studies, beginning with Jost Trier, focused on the analysis of certain lexical groups called Wortfelder ("lexical fields"), regarded as parts of a completely organized lexis. Their idealistic perception-according to which the whole lexis of a language has an inner organization that needs to be discovered-was confronted with some major issues. Our first observation, based on some examples from the lexis, reveals the fact that certain words cannot be classified as belonging to a specific lexical field. Another observation is related to the semantic continuum of the lexical field, which is compared in some works with the image of a mosaic. These issues are detailed by the argumentations of the German lexicologists, whose research was based on a diachronic analysis of the lexis. Their views were exploited in the second stage of the theorization of lexical fields.
\end{abstract}

\section{Introduction}

Any human cognitive activity implies first and foremost the identification of the object (that can be more or less accurate) followed by the identification of the parts that the respective object is made of. When it comes to verbal language it is basically believed that the constituent elements are the words, although the value of morphemes was identified by the old Indians ages ago. The words regarded as constitutive elements of the language display similar issues with the language itself, as long as they are regarded as individualities, that is without considering their functioning plan. One of the issues that is common to both levels - that of the language and of the constitutive elements of the language, namely words-is the relation with the designated realities and the concepts corresponding to those realities. The attempt to establish the nature of this relationship has encountered countless difficulties both in the philosophical approaches and in the strictly linguistic ones.

The relation of the words with the designated reality (with a first concretization in the question regarding the "right denomination of things" questioned by the ancient Greeks) can still be considered valid at the level of analysis of the constitutive elements, especially with regard to the definition of onomatopoeic words (when the fact that they are also based on a convention is not taken into account). The relation with the conceptual level, whose beginnings can be identified in Locke's (1961) observations regarding the human intellect, is highlighted by Humboldt (2003) and applied in the German lexicologists' studies conducted in the mid-20 ${ }^{\text {th }}$ century, especially by Weisgerber $(1973$, p. 196), who coined the concept of 'intermediate world', Germ. Zwischenwelt. Regarding the conceptual level, a preliminary clarification is absolutely mandatory, as it must not be confused with the intellectual (of thought or imagination) or psychic (emotional) realities, since these have their own conceptual representation. For instance, the Romanian word patriotism 'patriotism' corresponds to various realities (conceived in relation to a specific period and cultural environment), yet the concept is a simplified one, a schema of this reality that could be

\footnotetext{
*Email address: dinu.moscal@gmail.com.
} 
rendered by "love for the homeland" (without no details regarded the way it manifests). A psychic reality such as the feeling of hatred is designated in Romanian by the word ură 'hate', which corresponds to a simplified concept ('a feeling of resentment directed towards someone or something'), but the reality of the feeling is a complex matter that differs from one individual to the other. The analysis of these relations at the general level of verbal language lies with philosophical or language philosophy research. As far as the second level - that of the words regarded as units outside the functioning plan-is concerned, these relations have been considered in the research of the language before the emergence of linguistics as a science, especially in etymological research, joined subsequently by semantic research.

The objective of this study takes some distance from the first level and is thus concerned with the analysis of the status of words in relation to the designated reality and its corresponding concepts. The reference period is the second third of the last century, when German lexicology was marked by a series of high-level contributions regarding the concept of the 'lexical field'. One of the most debated and criticized aspects of the theory is related to the degree of overlap between a conceptual area and the corresponding semantic area (consisting of concepts that could be included in a broader concept or in a relatively limited field) represented by a lexical field at the level of the lexis. In their first stage, lexical theories regarded the entire lexicon of a language as being organized into lexical fields, while the linguists' role was merely to identify the various types of structures belonging to these fields. The analysis of the degree of overlap between the semantic area and the conceptual area requires the consideration of both the semantic area limits and its continuity (or discontinuity). Thus, this latter aspect raises the issue of the semantic delimitation of the words regarded as discrete realities (defined in relation to the words with which they share a common meaning), as are, in fact, all cultural realities. This study aims at highlighting the contributions of the scholars from the second third of the $20^{\text {th }}$ century to the elaboration of a lexical semantics as appropriate as possible for the object under investigation. The analysis of the critical observations issued during this period with regard to the concept of 'lexical field' and the assimilation of these ideas in the subsequent period testify on the merits of the representatives of the beginnings of structural semantics.

\section{Historical background}

The concept of the 'lexical field" is used with various meanings and under different names before the establishment of structural semantics. Yet the basic contribution of the studies on this topic is the discovery of a typology of the way in which the terms that make up an onomasiological field are related and mutually delimit their content. The theories start from a general picture of the language, as depicted by Humboldt (2003, p. 335):

Man kann die Sprache mit einem ungeheuren Gewebe vergleichen, in dem jeder Theil mit dem andren und alle mit dem Ganzen in mehr oder weniger deutlich erkennbaren Zusammenhange stehen. ${ }^{2}$ / Language can be compared to an immense web, in which every part stands in a more or less clearly recognizable connection with the others, and all with the whole. (Humboldt, 1999, p. 69)

The delimitation of groups of words based on their common meaning is an important step in the study of the lexis, as the lexicographic definition could overcome a strictly descriptive definition and could also indicate its relation to the words with which it shares an area of common significance. Ultimately, a commonly accepted truth as far as language is concerned (valid for all cultural realities) is the fact that its entities are not of a concrete nature, but rather of a discreet one (a feature that should be directly related to Saussure's concept of 'value'). These approaches are basically aimed at organizing the lexis of a language into fields_-delimited by means of the onomasomological method-and at identifying a

\footnotetext{
${ }^{1}$ This article discusses issues previously surveyed in Moscal (2013, p. 38-84).

${ }^{2}$ The quotation preserves the original text spelling ("man" for "mann", "andren" for "anderen", and "Theil" for "Teil").
} 
typology of the internal organization of the fields, which highlighted the semasiological challenges. The internal description of a field is based on some differences that occur at the diachronic level, according to the method developed by Trier (1973), which demonstrates the interdependence of the elements within a lexical field.

\section{The semantic area at the level of lexical fields and the semantic content of words}

One of the basic characteristics of the lexical fields theory in this stage is the belief that there exists a complete coverage of the corresponding semantic area, an aspect emphasized by Kandler (1973, p. 352):

Dieses Theorem der Lückenlösigkeit spielt in der Theorie des sprachlichen Feldes und der damit verbundenen Sprachteorie eine wesentliche Rolle [This theorem regarding the lack of gaps plays an essential part in both the lexical fields theory and in the corresponding language theories].

Tracing the theoretical origins of the concept of 'lexical field' one may note that this feature originates from the theoretical calque-like image of the language described by Humboldt, according to whom language as a whole is a counter-image of the conceptual world. Trier (1934, p. 429, see infra) takes over this perspective-which can be regarded as accurate, provided that it is applied to the general level of language - and transfers it upon the lexis, regarding the latter as being made of a network of lexical fields. The transfer of Humboldt's perspective upon language towards the theoretical level is also adopted by Saussure, who proposes the concept of 'associative family' ${ }^{3}$, without considering the limitation of these associations to a single type, as Trier attempts to demonstrate. Even if language was regarded as a complete representation of the conceptual world, this would not necessarily mean that this representation is situated at the lexis level. Conceptual reality is accessible to language, yet the latter cannot be forced to display symmetry with regard to the conceptual reality as far as the form of expression is concerned (see Hjelmslev, 1967, p. 115). Bloomfield (2005, p. 278) emphasized this aspect clearly:

What one language expresses by a single morpheme will in another language require perhaps a long phrase; what one language says in a word may appear in another language as a phrase or as an affix.

This observation regarding the level of language's form of expression indicates that a "conceptual block" can be articulated through language at the level of expression without it being exclusively situated at the lexical level, while certain concepts are rendered at least by syntagms or periphrases. For instance, the concept of 'high heeled shoe' has a corresponding term at the lexical level in German, namely Stöckelschuh, which is part of the lexical field "(die) Schuche" 'footwear' but does not have a corresponding term at the lexical level in Romanian, where it is expressed by the phrase "pantof cu toc înalt" ("high heeled shoe"), and therefore does not belong to the lexical field "încălțăminte" ('footwear'). However, the existence into another language of a lexical equivalence is not mandatory for identifying a concept that could be expressed by means of more than one lexeme in another language. Certain concepts, especially the ones corresponding to the imagined reality, are not mirrored by the lexical level of the language. In this case, Trier's approach of the lexical fields that display a complete and compact structure becomes questionable. Weisgerber (1962, p. 205-242) already provides a clue in this respect, by mentioning the special cases of

\footnotetext{
3 “Un terme donné est comme le centre d'une constellation, le point où convergent d'autres termes coordonnés, dont la somme est indéfinie". (Saussure, 1922, p. 174) / "A particular word is like the center of a constellation; it is the point of convergence of an indefinite number of co-ordinated terms". (Saussure, 1966, p. 126)

${ }^{4}$ „[Das Wortfeld] ist also die äussere, zeichenhafte Seite der begrifflichen Aufteilung, die jener Begriffskomplex, Begriffsblock, Begriffsbezirk durch und für die Sprachgemeinschaft erfährt" " [The lexical field] therefore represents the external feature, of a sign nature, of the conceptual distribution that results for that specific conceptual complex, conceptual block, or conceptual sphere, through and for the linguistic community"]. (Trier, 1973, p. 1)
} 
certain words in which it is difficult to perform a delimitation of their semantic content and therefore to frame them into specific fields: semiabstract onomatopoeic words germ. (Germ. brüllen 'to roar', brummen 'to mumble'), "affective words" (Germ. Heimat 'homeland', Geist 'spirit'), as well as idioms and poetic creations.

Reuning (1973, p. 256-257) as well provides an observation on the inner organization of a field: "Trier glaubt nicht an die «Diskontinuität der sprachlichen Welt», und er versichert uns, zumindest in seiner Theorie, dass das Feld «lückenlos» ist" ["Trier fails to consider «the linguistic reality discontinuity» and insures us, at least in theory, that a linguistic field «does not have any gaps»"] ${ }^{5}$. Reuning uses Trier's own examples to provide arguments regarding the lexical field of "knowledge" (Germ. Verstand) analyzed from the perspective of the German language evolution. It must be noted that throughout different stages, certain words for notions belonging to this conceptual field keep appearing and disappearing. Reuning makes reference to Trier's observation regarding the inexistence in old German of a word corresponding to the concept of 'pure intelligence':

Der reine Klugheitsbereich hat keine eigenen Worte. Die wachsen ihm mit klug und gescheit erst im 14. Jahrhundert zu [The field of pure intelligence did not have specific words. These only started to appear in the $14^{\text {th }}$ century due to $k l u g$ and gescheit]. (Reuning, 1973, p. 257)

To this example Reuning adds one of Schopenhauer's comments regarding the attempt to find a German equivalent for the Greek concept sophrosyne:

Daher also muss man, bei Erlernung einer fremden Sprache, mehrere ganz neue Sphären von Begriffen in seinem Geiste abstecken: mithin entstehen Begriffssphären, wo noch keine waren. Man erlernt also nicht bloss Worte, sondern erwirbt Begriffe [Therefore, when learning a foreign language one must mentally delineate completely new spheres at the conceptual level: thus, conceptual spheres arise that were yet inexistent. Consequently, one does not only learn words, but acquires contents]. (Arthur Schopenhauer, Sämtliche Werke, Reclam, Band 5, p. 599, apud Reuning, 1973, p. 257)

Reuning's and Schopenhauer's observations are accurate, yet Reuning's comments do not provide a clear and necessary distinction regarding the discontinuity of the linguistic reality (Germ. die sprachliche Welt).

Based on Humboldt's ideas, Trier believes that there exists a continuity of the linguistic world for speakers and this continuity consists in the organization of the lexis into fields:

Das Seinsbild einer Sprache ist ein Kontinuum, es enthält keine Lücken und blinden Flecke für den Sprachgenossen (our underlining) [The image of the reality of a language is a continuum, it contains neither gaps nor blind spots for the speakers (our underlining)]. (Trier, 1934, p. 429)

However, the discontinuity of the fields does not necessarily imply the discontinuity of the linguistic reality. For instance, if Romanian does not provide different terms for 'uncle' and 'aunt' on one's mother's or father's side, this does not mean that the language, in its entirety, does not express this distinction. Whereas we can identify a discontinuity of the lexis, we cannot speak of a discontinuity of the language and therefore we must reconsider Reuning's arguments, as they do not differentiate between a language in itself and the lexis of that language. The examples related to the lack of words in old German for the concept of 'pure intelligence' and Schopenhauer's comment refer to another reality. The fact that no words were available in old German for the concept of 'pure intelligence' can be explain from a twofold perspective: either the concept already existed, without being lexicalized, or (less probable) the concept did not yet exist. Neither of the two cases above indicates a discontinuity of the linguistic world. The

\footnotetext{
${ }^{5}$ See also Schwarz (1973, p. 430-433).
} 
first case actually corresponds to the above-mentioned example regarding the lexicalization of the 'highheeled shoe' concept in German by Stöckelschuh and its lack of lexicalization in Romanian. On the other hand, the second case corresponds to the situation described by Schopenhauer when it comes to learning a foreign language, i.e. operating new distinctions at the linguistic reality level, which corresponds to Trier's theory regarding the conceptual complex/block or the conceptual sphere and the lexical field. According to Trier, a lexical field is the articulate linguistic representation of a non-articulate conceptual block. The analysis of a lexical field consists in tracing the articulation of these conceptual areas. Therefore, the lexicalization of either a new distinction or an already existing distinction that has not yet been lexicalized represents the very proof of the existence of lexical fields. Therefore, what Reuning should have noticed is the fact that not all concepts have a correspondent at the lexical level of the language.

The above arguments are basically valid for the lexical neutralizations of some distinctions that can be identified in the conceptual area. Wartburg (1946, p. 141-142) signals the lexical distinction between the mother's side and the father's side for the concepts of 'uncle' and 'aunt' in Latin, a distinction that was preserved by none of the Romance languages. For the concepts of 'uncle' and 'aunt', Romanian no longer makes any distinction between the maternal and the paternal genealogy, so that for the Latin avunculus 'maternal uncle' and patruus 'paternal uncle' Romanian provides only the term unchi [uncle], while the Latin matertera 'maternal aunt' and amita 'paternal aunt' are designated in Romanian by mătuşă [aunt]. A similar situation can be identified in the individual history of a language. For instance, in pre-modern Romanian there functioned a different distinction regarding the dichotomy vechi - bătrîn [ancient old]: bătrîn functioned as an archilexeme for vechi. As it is still the case nowadays, vechi used to refer to everything that was inanimate ${ }^{6}$; on the other hand, bătrîn was used for any reality (whereas currently it is used to indicate animacy). This aspect is confirmed by old documents and by a series of toponymic syntagms in which the term was preserved, such as Măgura Bătrînă (East of Cîmpulung Moldovenesc, the county of Suceava), Plaiul Bătrîn (West of Boboiești, the county of Neamț), Jijia Bătrînă (a tributary of the river Jijia) or Jiul Bătrîn (a lake in the county of Dolj). During the $17^{\text {th }}$ century and at the beginning of the next the above-mention distinction had not been established yet, as indicated by the documents dating from that period.

The non-lexicalization of concepts that are otherwise lexicalized in other languages or even within the same language, in different stages, does not imply a discontinuity of the language. Elements that are not yet conceptualized, as in the example provided by Schopenhauer or in the case of old German words for 'pure intelligence', do not necessarily imply a discontinuity of the linguistic reality. One cannot speak of a discontinuity of the language at a general level, since everything that became accessible to rational knowledge can be expressed through language, regardless of the fact that the level of expression might vary from the affix to the phrase or text. However, we can speak of discontinuity at the lexical level of the language, since not all the individual concepts expressed through a language are rendered by means of a lexeme. The component elements of the lexical field "încălțăminte" [footwear] in Romanian include quite a large number of words (pantof [shoe], cizmă [galosh], opincă [opanak], mocasin [moccasin], gheată [harness boot], bocanc [work boot], cipic [flip-flop], sanda [sandal], etc.), yet, they do not cover the whole range of footwear known by the speakers of Romanian. For instance, there are no individual lexemes that mark the distinction / fără toc [flat sole]/ - /cu toc [heeled]/ or / fără toc [flat sole]/ - /cu toc [heeled]/ - /cu toc înalt [high-heeled]/; in such cases syntagms such as "cizme fără toc" [flat sole boots], "cizme cu toc" [heeled boots], "cizme cu toc înalt" [high-heeled boots], etc. are used.

The distinction between the conceptual, extra-linguistic, level, the general linguistic level and the lexical level cannot be ignored when performing such an analysis. The first two can be regarded as parallel, in the sense that any concept can be expressed through language, yet the third level represents just a part of the linguistic level. We should restate the fact that the conceptual level is not symmetrical with the linguistic level. . A certain degree of parallelism does exist, from the perspective that language reflects

\footnotetext{
${ }^{6}$ The syntagm "țuică bătrînă” [țuică = strong traditional Romanian alcoholic drink] reflects this older reality.
} 
concepts, yet not completely, since a concept can also comprise non-linguistic features that originate from other types of knowledge (psychological, tactile, etc.), different from the linguistic one. Trier (1973, p. 1, see supra, footnote 3) counts on this parallelism when he speaks about conceptual fields ("Begriffsfelder") and lexical fields ("Wortfelder"). A conceptual field designates the representation, organized by means of a language, of a conceptual block ("Begriffsblock") which is inarticulate outside language. The degree in which the language operates distinctions in the content of this conceptual block has no relevance whatsoever regarding the continuity of the linguistic reality. Whatever is not differentiated within a semantic block, it is not missing, but it exists latently in a non-differentiated way within a larger concept. If the differentiation is performed at the general level of the language and not by means of a specialized lexeme, the lexical field cannot be regarded as discontinuous when it covers the entire semantic area of a conceptual block by means of the elements composing it at a more general scale (see the example wisheit kunst - list provided by Trier, 1973). These discontinuities are perceived as such only in the case of certain disymmetries in the organization of a field, as it is the case of the field "vehicul" [vehicle] in Romanian, where there are no specific words that would designate the category of two-wheeled vehicles as opposed to the category of four-wheeled vehicles or vehicles with any other number of wheels. Whatever is not differentiated in language or was differentiated at a lexical level and then neutralized (see the case of Romanian unchi - mătuşă, similar in the other Romance languages, as well) cannot be regarded as a discontinuity at either the lexical level or the lexical field level. The Romanian unchi comprises the whole content of the Latin terms avunculus and patruus, whiel Rom. mătuşă comprises the content of matertera and amita. As a matter of fact, this is not an issue of discontinuity, but it rather indicates a non-differentiation (or a sub-differentiation) at the lexical level of the Romanian language, a situation that is solved by using the syntagms "unchi din partea tatei" [uncle on one's father's side], "unchi din partea mamei" [uncle on one's mother's side], etc.

At times, the lexical fields theory is perceived only through the perspective of the possibility to clearly delineate the semantic content of each element regarded beyond the lexical field, in other words, the very purpose of the lexical field theory when it situates each word in relation to the other word that belong to the same semantic area. These observations are especially related to the cases of polysemy and synonymy and occasionally to metaphorical meanings, cases in which a word is apparently difficult to frame in a specific semantic area. The definition of the semantic content of words has been attempted by several authors, either from a general perspective upon the lexis (Funke, 1954; Haller, 1963), or with direct reference to the theory of semantic fields (Reuning, 1973; Müller, 1957), yet without providing a viable solution that could be applied to the lexical field theory. Kandler (1973, p. 360-362) proposes a solution in the case of homonyms and polysemous words. According to him, a polysemous word must be treated in the same way as a homonym while, as in the case of homonyms, each meaning of a polysemous word is an element that belongs to a different lexical field. Kandler provides two examples: Germ. Bank [bench/bank], for homonymy (/to sit on/ - /financial institution/), and Fleisch [flesh/meat], for polysemy (/part of the body/ - /food/).

The German lexicologists approaches meant to elaborate a coherent theory of the lexical fields would have the opportunity of providing actual solutions when Hjelmslev's Prolegomena to a Theory of Language (1967), was issued, yet his distinctions were initially ignored, although they were later exploited with great results by (see also infra). By observing that content and expression actually present a second dichotomy, namely form - substance, and that the study of language takes into account this double aspect of the form, the issue of polysemy and synonymy emphasize the relation between the form of the lexical content and the form of lexical expression. The semantics works issued in the following period also failed to include this distinction. Ullmann (1975) does not mention the work of the Danish linguist at all. Only years later, Greimas (1966, p. 25-26) incorporates this distinction in the semic analysis and elaborates his work based on another of Hjelmslev's (1971) contributions. The possibility to describe lexemes by means of semes was about to exercise a huge influence upon the study of lexical fields, as it has the advantage of a more exact positioning within the lexical field for each of its elements. Hjelmslev believes that without structural 
semantics lexicology is limited to a mere enumeration and definition of words, being nothing more than a lexicography:

A première vue, le vocabulaire reste capricieux et juste le contraire d'une structure. C'est pourquoi tout essai pour établir une description structurale du vocabulaire, et, à plus forte raison, une sémantique structurale, semble être voué à l'échec et devient facilement la proie du scepticisme. C'est aussi pourquoi la lexicologie reste une case vide dans la systématique de notre science, et qu'elle se réduit forcément à n’être qu'une lexicographie, ou simple énumération d'un effectif instable et indécis de certaines grandeurs mal définies auxquelles on attribue un fatras inextricable de multiples emplois différents et apparemment arbitraires [At a first sight, vocabulary remains apparently capricious, exactly the opposite of a structure. This is why, any attempt to establish a structural description of vocabulary and even more so a structural semantics, seems to be doomed to failure and prone to scepticism. Therefore, lexicology continues to be an empty box in the systemic of our science, confined within the limits of either lexicography or a mere enumeration of an unstable and uncertain force made up of a series of poorly defined sizes, which are attributed a confusing amount of numerous, diverse and apparently arbitrary usages]. (Hjelmslev, 1971, p. 106-107)

The concrete semantic description (by means of semantic features) of words (lexemes) emphasizes the relations between the elements of a field as well as their meaning in the respective field. Yet, this description is only apparently concrete (without being related to other lexemes), since the words continue be discrete units, that is to say they are defined only in relation to the lexemes with which they share a common significance. Semantic features provide a word with an apparent status of concrete individuality; yet, they represent the outcome of relating the word(s) with which they share a common feature (with regard to both common and distinctive features) with one or more opposing features (distinctive features). The fundamental principle of defining words semantically is still the one that the first theories of the semantic field are based on. Even if the next stage of lexical fields theorization is based on Trubetzkoy's phonology (1977, p. 60-80), this cannot be perceived separately from the German lexicologists' studies conducted in the second third of the last century, which in principle do not differ from phonology, a discipline that also describes discrete units. Denying the possibility of a completely organized lexis, along with acknowledging the discontinuity of certain lexical fields are crucial for the delimitation of research on this topic, an aspect that was also highlighted by Coseriu's definition of the 'lexical field':

Un champ lexical est une structure paradigmatique constituée par des unités lexicales se partageant une zone de signification commune et se trouvant en opposition immédiate les unes avec les autres [A lexical field is a paradigmatic structure consisting of lexical units that share a common area of significance and are in a relation of immediate opposition to one another]. (Coseriu, 2001, p. 321)

This definition was later improved by adding the specification "partageant une zone de signification continue (our underlining) commune [sharing a continuous (our underlining) common area of significance]" (Coseriu, 2001, p. 385), although it can be stated that the continuity feature of the significance area can be deduced from the syntagm "se trouvant en opposition immédiate les unes avec les autres" included in the first definition.

\section{Conclusions}

The views of the German lexicologists regarding the concept of 'lexical field' led to a more accurate perspective upon the lexis and definitely impacted the subsequent research in the field. The idea that the lexis of a language has a complete and complex inner organization is already present in Humboldt's works, 
while the first attempts to prove its validity can be identified in the German area in the second third of the last century. The diachronic analysis of onomasiological fields proved the semantic interdependence of the constitutive terms, providing solid arguments for the subsequent research aimed at building an articulate theory of lexical fields. The initial assumption according to which an entire structural network for the lexis of a language could be identified could not be proved, yet observations targeted the partial achievements, consisting in the first attempt to theorize lexical fields. A contribution that should be emphasized results from the observations regarding the discontinuity of lexical fields which indicate that the discrete realities status of lexemes (that is in relation to other lexemes) does not imply that they share common limits, but it rather indicates that discontinuities might occur at the level of the lexis. Subsequent research has assimilated the critical observations regarding the structuring of the lexis, which resulted into a more accurate approach and consequently a deeper understanding of the lexis of a language.

\section{Bibliography}

Bloomfield, L. (2005 [1935]). Language, Motilal Banarsidass Publishers, New Dehli.

Coseriu, E. (2001 [1968]). Les structures lexématiques, in L'Homme et son langage, Textes réunis par H. Dupuy-Engelhardt, J.-P. Durafour et F. Rastier, Éditions Peeters: Louvain - Paris - Sterling, Virginia, p. 315-331.

Funke, O. (1954). Form und Bedeutung in der Sprachstruktur, în „Sprachgeschichte und Wortbedeutung. Festschrift Albert Debrunner gewidmet von Schüllern, Freunden und Kollegen”, Franke Verlag, Bern, p. 141-150.

Greimas, A.-J. (1966). Sémantique structurale. Recherche de méthode, Moreau et Cie, Paris.

Kandler, G. (1973 [1959]). Die „Lücke” im sprachlichen Weltbild, în „Wortfeld-forschung. Zur Geschichte und Theorie des sprachlichen Feldes”, Hrsg. von Lothar Schmidt, Wissenschaftiche Buchgesellschaft, Darmstadt, p. 351-370.

Haller, R. (1963). Wörter, Bedeutungen, Begriffe, în „Sprache im technischen Zeitalter”, 8, p. 595-607.

Hjelmslev, L. (1967 [1943]). Preliminarii la o teorie a limbii, Traducere de D. Copceag, Centrul de Cercetări Fonetice și Dialectale, București.

Hjelmslev, L. (1971 [1957]). Pour une sémantique structurale, în „Essais linguistiques”, Minuit, Paris, p. 105-121.

Humboldt, W. von (1999). On Language. On the Diversity of Human Language Construction and its Influence on the Mental Developement of the Human Species, Translated by Peter Heath, Cambridge University Press, London.

Humboldt, W. von (2003 [1836]). Über die Verschiedenheit des menschlichen Sprachbaues und ibren Einfluss auf die geistige Entwiklung des Menschengeschlechts, în vol. Über die Verschiedenheit des menschlichen Sprachbaues und ibren Einfluss auf die geistige Entwiklung des Menschengeschlechts. Über die Sprache, Fourier Verlag, Wiesbaden.

Locke, J. (1961 [1790]). Eseu asupra intelectului omenesc, vol. I-II, Traducere de Armand Roșu și Teodor Voiculescu, Editura Științifică, București.

Moscal, D. (2013). Teoria câmpurilor lexicale. Cu aplicație la terminologia populară a formelor de relief pozitiv, Editura Universității „Alexandru Ioan Cuza”, Iași.

Müller, G. (1957). Wortfeld und Sprachfeld, în „Beiträge zur Einheit von Bildung und Sprache im geistigen Sein. Festschrift zum 80. Geburtstag von Ernst Otto", Hrsg. von Gerhard Haselbach und Günter Hartmann, Walther de Gruyter \& Co., Berlin, p. $155-163$.

Reuning, K. (1973 [1941]). Die Feldtheorie, în „Wortfeldforschung. Zur Geschichte und Theorie des sprachlichen Feldes”, Hrsg. von Lothar Schmidt, Wissenschaftiche Buchgesellschaft, Darmstadt, p. 226-277.

Saussure, F. de (1922). Cours de linguistique générale, publié par Charles Bally et Albert Sechehaye avec la collaboration de Albert Riedlinger, Payot \& Cie, Paris.

Saussure, F. de (1966). Course in General Linguistics, edited by Charles Bally and Albert Sechehaye in collaboration with Albert Reidlinger; translated from the French by Wade Baskin, McGrawe-Hill, New York.

Schwarz, H. (1973 [1966]). Zwölf Thesen zur Feldtheorie, in "Wortfeldforschung. Zur Geschichte und Theorie des sprachlichen Feldes”, Hrsg. von Lothar Schmidt, Wissenschaftiche Buchgesellschaft, Darmstadt, p. 426-435.

Trier, J. (1934). Das sprachliche Feld. Eine auseinandersetzung, in "Neue Jahrbücher für Wissenschaft und Jugendbildung", 10, p. 429-449.

Trier, J. (1973 [1931]). Der deutsche Wortschatz im Sinnbezirk des Verstandes. Von den Anfängen bis zum Beginn des 13. Jahrhunderts, Zweite Auflage, Carl Winter Universitätsverlag, Heidelberg.

Trubetzkoy, N.S. (1977 [1939]). Grundzüge der Phonologie, Vandenhoeck \& Roprecht, Göttingen.

Ullmann, S. (1975). Précis de sémantique française, Éditions A. Franke S. A. Berne, Bern.

Wartburg, W.v. (1946). Problèmes et méthodes de la linguistique, PUF, Paris.

Weisgerber, L. (1962 [1950]). Die sprachliche Gestaltung der Welt, 3. neuarbeitete Auflage, Pädagogischer Verlag Schwann, Düsseldorf.

Weisgerber, L. (1973 [1939]). Vom inhaltlichen Aufbau des deutschen Wortschatzes, in "Wortfeldforschung. Zur Geschichte und Theorie des sprachlichen Feldes”, Hrsg. von Lothar Schmidt, Wissenschaftiche Buchgesellschaft, Darmstadt, p. 193-225. 